*This is the prefinal manuscript; the fully finalized version has been

published in Posthumanism and Higher Education (2019):

https://www.palgrave.com/gp/book/9783030146719\#aboutAuthors

\title{
Re-vitalizing the American Feminist-Philosophical Classroom. Transformative Academic Experimentations with Diffractive Pedagogies
}

Evelien Geerts

Introduction: The need to re-vitalize higher education pedagogy in contemporary neoliberal times

Present-day higher education is in dire straits. Even though global youth literacy and education participation rates have been on the rise (UNESCOstat, 2017; UNdata, 2018), and the democratization of education has become a top priority for human rights-driven agencies such as UNESCO (UNESCO, 2016), it is at the same time obvious that higher education institutions and pedagogical praxes should be pushed into more radical directions. For example, UNESCO's (2018) discourse on education still is drenched in the exclusivist human rights vocabulary of the Enlightenment: Given that such discourses neglect societies' marginalized Others as rights-deserving subjects, often ignore the impact of structural power imbalances, and disregard how human actors relationally co-exist with(in) human and nonhuman subjects and worlds, as many posthuman and new materialist scholars have noted (Barad, 2007; Braidotti, 2013; van der Tuin, 2015; Alaimo, 2016; Haraway, 2016), these discourses seem to be in an urgent need of an update. Higher education is, additionally, 
increasingly conceptualized in a development-based language, as UNESCO's example illustrates, which frames education not as a telos of its own but as an instrumental means to eradicate poverty or stimulate economic development. But it is the now worldwide-spread ideology of neoliberalism that is really damaging education as a formational praxis, as neoliberalism has materialized itself into what philosopher Wendy Brown in Undoing the Demos has called 'a peculiar form of reason that configures all aspects of existence' (2015: 17) (also see Foucault, 2008; Peck, 2010; Dardot and Laval, 2013 for similar analyses). Now a mode of governmental rationality, neoliberal reason has reduced citizen-subjects to mere homines oeconomici, and turned self-investment, hyper-individualism, and an enforced attitude of resilience into today's dominant modes of living.

All of this is particularly problematic because escaping the instrumentalizing claws of neoliberal reason seems impossible, since, to put it in a Braidottian way, every little piece of living matter - human and non-human - has been transformed into something sellable, profitable and potentially disposable (Braidotti, 2013). We all have become selfresponsibilizing market actors disciplined into calculating and promoting our worth. This has damaged our collective psychological well-being: as various psychiatrists indicate, hyperindividualism and de-rootedness engendered by neoliberal reason mean we are all living in 'borderline times' (De Wachter, 2012) in which meaning itself has been brutally economized, which makes fruitfully engaging in existentialist meaning-making praxes much harder. It has impacted on higher education as well. In such a context, contemporary posthuman and new materialist philosophies, for example Braidotti’s human-decentring '[z]oe-centred egalitarianism' (2013: 60) that emphasizes how life in all of its different and differing materialized forms is relationally connected because of a shared vital materiality, are in my view, more needed than ever before. Such philosophies, I suggest, are not only to help us 
make sense of the neoliberal world today but also offer a philosophical-political alternative, one that is suspicious of over-economization and states that everything of matter matters, and that there are productive ways out of the multitude of crises we are currently experiencing.

I take these concerns up from my situated viewpoint of an international instructor at a large public research university in the United States. My experience in the USA thus far has made it clear that institutions of higher education, its teachers, its programmes and disciplines - and even the material space of the classroom - are caught up in the same profit-focused and hyper-consumerist logics I outlined earlier, and are in dire need of re-vitalization. In this chapter I will take the reader on a journey of re-imaginings by sharing some of my personal intra-active experiences of co-learning with college undergraduates in an American classroom, while addressing how this neoliberalism-induced educational crisis can be affirmatively counteracted by experimentations with (feminist) new materialist theories and the methodology of diffraction (Haraway, 1997, 2004; Barad, 2007). I focus on the joint journey I went on with my students in the Winter of 2017 while teaching a course on feminist philosophy and new materialisms. I outline how the pedagogic experiments I undertook contested the monologic, dialectical nature of the Western philosophical canon, and how we actualized in our classroom various intersecting and energizing daily acts of resistance against the neoliberal corporatization of the university. Along the way, I include a variety of feminist new materialist pedagogical principles and tools. These experimentations will be examined in this chapter's final part to underline how feminist new materialist philosophies are actualized in the intra-actions between theory and praxis in the classroom, and how these philosophies could re-vitalize the American college classroom. 


\section{An affirmative critique of the negative impact of neoliberal profit-based thought on the}

\section{American college classroom today}

Starting from the claim that higher educational institutions around the world, and the Humanities in particular, are caught up in the earlier-described neoliberal logics (Groenke and Hatch, 2009; Nussbaum, 2010; Giroux, 2014), instructors and pedagogues are confronted with a corporatized educational model that does not centre on students' holistic formation. As indicated above, my concern in this chapter is how higher education pedagogy is being negatively affected by such a profit-focused logics. Writing myself into the traditions of critical, feminist and now also posthumanist and new materialist pedagogy (see Freire, 2001, 2006; Giroux, 1988, 2014 (critical pedagogy); see Aptheker, 1989; hooks, 1994, 2003 (feminist pedagogy); and see van der Tuin, 2015; Snaza et al., 2016; Hickey-Moody and Page, 2016; Braidotti et al., 2018 (new materialist-inspired pedagogy)), it seems that higher education in the United States is less and less about making students understand their place as engaged citizens in today's world and that of the future. Leaving the issue of declining social mobility aside (Leatherby, 2016), the core problem seen from a more micro, classroom-based standpoint is that we, as teachers, are being confronted with a pedagogical praxis in which students are to be spoon-fed easily-digestible materials in short sessions, demarcated by neoliberal academic clock-time.

Many in higher education fear that this is about promoting societal conformism, and what critical theorists Theodor Adorno and Max Horkheimer have called 'blindly pragmatized thought' (1997/1944: xiii), rooted in an educational banking system that reproduces socioeconomic inequalities, keeps the already-marginalized silenced, and into which teachers have to 'make deposits which the students patiently receive, memorize, and repeat' (Freire, 2006: 
72). My questions then are: Where in this disembodied form of instrumentalist instruction, and one-directional teaching and learning, is the scope for celebrating what black feminist thinker bell hooks calls '[e]ros [...] as a motivating force' (1994: 194)? How can we, as teachers, pedagogues and philosophers make a valuable pedagogical intervention in these neoliberal borderline times? And how can we create possibilities for such interventions that transcend the level of negative critique? I address these questions below in my discussion of some of the diffractive pedagogical strategies used during my 2017 class. I draw on the philosophies of Braidotti and Barad, in which 'critique and creation work hand-in-hand' (Braidotti, 2016) and critique is 'a practice of reading for the constitutive exclusions of those ideas we can not do without' (Barad in Dolphijn and van der Tuin, 2012: 49), to emphasize the entanglements between the ontological, epistemological, and the ethico-political. But first the genealogy of diffraction is briefly outlined (see Geerts and van der Tuin, 2016 for a fuller discussion).

\section{The feminist-philosophical classroom re-examined. The complex conceptual genealogy of diffraction}

Diffraction - next to being a physical phenomenon - has its roots in feminist science studies scholar Donna Haraway's oeuvre. Haraway's first engagement with diffraction appears in “The Promises of Monsters", an essay in which she refers to literary theorist Trinh Minh-ha's notion of inappropriate/d others - which expresses how subjects are 'in a diffracting rather than reflecting (ratio)nality', as Haraway also puts it (2004/1992: 69). Framed by Haraway's life-long project of 'epistemological electroshock therapy' (1988: 578), diffraction is a 'more subtle vision' (2004/1992: 70) than the traditional reflective scientific forms of optics and thought that is capable of revealing 'where the effects of difference appear' (70). Haraway in 
Modest_Witness@Second_Millenium later on expands on this by labelling diffraction as 'an optical metaphor' that stands in contrast with '[r]eflexivity' (Haraway, 1997: 16). The latter is a representationalist, distancing practice that 'displaces the same elsewhere' (16) and creates oppositional distinctions between the real and the figural, whereas diffraction is about making 'a difference in the world' (16) by paying attention to 'the interference patterns on the recording films of our lives and bodies' (16). Thinking and seeing diffractively for Haraway is thus a critical, situated, non-innocent way of thinking about the world that provides us with the opportunity to be more attuned to how differences - together with micro and macro webs of power - become materialized.

Philosopher-physicist Karen Barad's new materialist understanding of diffraction (Barad, 2007), which she integrates within agential literacy (Barad, 2000, 2001), builds on this Harawayan metaphor. Barad's take suggests that we, because of our agential being-with(in)the-world, are ethically responsible for our intra-actions - or intense, always entangled, coconstituting interactions - with(in) the world and each other. For Barad, the hermeneutics of diffraction expresses what a self-accountable feminist type of critique, and textual and pedagogical engagement, should consist of: Rather than employing a hierarchic methodology, diffractively approaching texts and theories means that they are dialogically read 'through one another' (2007: 93) to engender creative, unexpected outcomes. Diffraction is thus a valuable resource for higher education because it promotes a relational model of pedagogy and learning able to contest the now nostalgic, outdated Humanities-based educational models as well as the hyper-instrumentalized neoliberal ones. Diffractive thinking - in combination with an affirmative feminist politics - is inspirational, in my opinion, because it enables us to counter the many crises induced by a still dominant Eurocentric humanism, climate change, and present-day's neoliberal reason-fuelled increase in socio-economic inequalities, to name a 
few. Diffraction offers a prototype for pedagogy that is centred on critique and creativity, situatedness, geopolitical (self-)awareness, accountability, and an immanent ethical attitude that takes current-day political constellations and complications into account. The remainder of this chapter puts diffraction into practice and takes the reader on my own feminist new materialist-inspired pedagogical journey of re-imaginings.

\section{The feminist-philosophical classroom re-vitalized. Diffractive pedagogical approaches and tools}

\section{Pedagogic context}

At the start of the eleven weeks Winter term, I was excited to work with my students on various challenging topics - such as feminist science studies; queer, disability and critical race studies; critiques of which bodies come to matter in society and in new materialist thought; the contested validity of academic critique in today's post-truth climate - using different transdisciplinary frameworks and authors. My feelings of excitement however quickly turned into concern upon realizing that many of the registered undergraduates not only came from different disciplines (feminist theory, literature, history of consciousness, politics, chemistry, and Latin American and Latino studies) but also had never taken any philosophy courses before. This forced me to carefully and continuously reflect upon my own teaching pedagogy and usage of - often rather alienating - philosophical jargon. Furthermore, time pressures there were only eleven weeks of class that had to be taught in two ninety-minute sessions per week - and life pressures - many of my students had jobs, were dealing with complex personal issues, and felt financially pressured to graduate as fast as possible - meant that we frequently all showed up to class with drained bodies and brain fatigue. The pedagogic 
context, then, was one in which we were constantly being pressured by neoliberal reason and academic clock-time, which made it hard for the students to be as intellectually invested as they would have liked to be, and made it at times equally difficult for me to teach in a truly dialogical, communal manner.

I had initially planned to experiment with dialogical pedagogy and a radically-altered idea of collaboration to foster more knowledge production from the ground up, thereby following in the footsteps of anthropologists Anna Tsing and Miyako Inoue (Choy et al., 2009), who use the notion of "“strong collaboration"” (Tsing in Choy et al., 2009: 381) to describe their situated, collective research praxis as a means of fore-fronting more creative, open-ended, and in a way diffracting and diffractive research, thereby going against academia's neoliberalization in which individualism and unhealthy competition are now core principles. I however soon found out that both teachers and students are constantly restricted by certain systems and their limits - whether it be the academic educational system itself (grade letter evaluations were for instance required), the classroom's limited physical space, or the educational-cultural capital we have grown up with. These phenomena at times forced me to step back into a more instructional-based didactic pedagogy. But amidst trying to find the balance between didactics, dialogue, and said idea of strong collaboration, there were surprisingly also a couple of non-traditional, diffractive pedagogical strategies and tools that were engendered through our collective acts of resistance against the further neoliberalization of our institution and class environment. And these strategies were informed by several pedagogic principles as well, while at the same time reciprocally intra-acting with the latter, and slowly but surely transforming them into principles that could be interpreted as feminist new materialist. I discuss both types of intra-ventions in what follows.

\section{Diffractive intra-ventions \& feminist new materialist-inspired principles}


The jointly-designed syllabus

At the start of our intense period of co-learning, I knew that I wanted to disrupt the educational banking system as much as I could, and my students had likewise expressed their interest in experimenting with a less didactics-based pedagogy. After having some introductory conversations, in which I also explicitly opened up about my own situated position - i.e. that of a white, Western European queer woman from a working-class neighbourhood - and how those elements affect my teaching praxis, we decided that we wanted to try and break through the traditional power hierarchies-based gap between instructor and instructed, a gap that is central to both more classic and nostalgic Humanitiesbased pedagogies and the neoliberal instrumentalist ones. We wanted to become co-learners, and one way to do so was by experimenting with the traditional academic syllabus. This reimaging of the syllabus felt particularly necessary, as several students with Native American heritage at the start of class had shared their negative experiences with the field of science studies, and how they felt like Western scientific knowledge production processes had for centuries delegitimized their onto-epistemological relational understanding of the world. Limited by the traditional evaluative framework of the university, however, we did start out with a collection of various texts regarding feminist philosophy and new materialisms, as one must hand in a sample syllabus before getting a course approved. But wanting to consider all of our situated lived experiences and knowledges, we quickly decided to experiment with a syllabus that would remain re-designable throughout the course, as to incorporate even more articles and essays that resonated with the students' experiences and interests. The jointlydesigned syllabus thus intra-actively came into being, and was meant to be ever-evolving. And even though that made everyone anxious at first, being confronted with a lot more 
academic freedom than usual, we had many productive discussions about the limitations of the Western canons of philosophy and feminist theory with regards to the (de)legitimization, marginalization and exploitation of certain subjugated knowledges; especially in relation to particular local Indigenous knowledges and relational onto-epistemologies. This jointlydesigned syllabus could be regarded as a diffractive pedagogical strategy-in-action, as it not only materialized some of the negative affects students had about the university and the classroom as (de)legitimizers of certain knowledges and world orientations, and morphed these feelings into something more affirmative, but it also demonstrated some of the critical creativity that is so central to the Harawayan-Baradian idea of diffraction. This experiment was also a concrete materialization of our shared wish to subvert the dichotomized ways of binary-thinking and the onto-epistemological cuts (see Barad, 2007) between the so-called knowledge-producing subject/examined object/knowledge produced that are central to more traditional learning systems: We were now at least partially co-learners, intra-actively encountering one another in dialogue, and the joint syllabus was an expression of attempting to treat one another as situated agential actors with valuable lived experiences. And in this more strong collaboration-based context, the ideal of purported neutral and one-directional knowledge production and transference was deconstructed in a feminist, accountable manner (Haraway, 1988) by making space for everyone's perspectives and opinions in class while taking a step back as the instructor when needed.

The collaborative Google Documents-based midterm

Wanting to step out of the traditional evaluative framework, we also collectively thought about redesigning the midterm exam during the first two weeks of class and decided that a collaborative Google Documents-based writing project would be ideal: All of the students were asked to write about a material-discursive phenomenon that they themselves were 
allowed to pick, such as gold, UCSC's geographical location, the components of a laptop, ..., while trying to trace this specific phenomenon's ethico-political entanglements; an exercise that was philosophically inspired by Barad's agential realist philosophy of entanglements and philosopher of science Bruno Latour's Dingpolitik (Latour, 2005). Because of the focus on entanglements, the exercise was already transcending mere description and reflection - as the students were explicitly asked to think about how certain phenomena like resource-based neoliberal capitalism, the production of laptop components, Hewlett-Packard, and the American military industrial complex are all connected to one another. Instead of having to fill out some midterm questions on a couple of sheets of paper, students now had to collaborate with one another on an online platform. They were asked to write creative essays together by using a Google Document that was shared with the whole class so that we could all be part of the writing-process-in-action. This project worked out really well: While it started out as another tiny act of resistance against the hyper-individualization and selfresponsibilization that is now so central to American academia, the experiment quickly transformed into a pedagogical strategy worthy of the label of diffraction. The Baradian idea of dynamic intra-actions even came to the foreground, as all students ended up digitally commenting on the pieces, therefore breaking out of their solipsistic learning bubbles. Plus, the end-result also showed us the multiple intra-active re-visions that had been made during the rewriting processes - which reminded me of Barad's agential realist queering of temporalities and the idea of re-configurations (Barad, 2007, 2010). Everyone really felt part of and responsible for this intra-active writing assemblage, which was a great event to witness!

\section{Classroom-based memes}


The final potentially diffractive pedagogy that came into being during our time together as colearners in this class, has to do with memes. Memes are (non-)textual photo-based images that are digitally circulated amongst Internet-users because they are expressing - and often also are giving a twist on - a certain socio-cultural idea or practice. Memes are said to go viral once a huge amount of people belonging to the same online community start employing them as a means of socio-political commentary.

The memes that I came up with during our eleven weeks of class, some of which ended up on my Subversive Philosophy Memes-Tumblr, were a mix of socio-political and pedagogical commentary. I will briefly discuss a couple of memes that were engendered during our intense class intra-actions and that were later on pedagogically re-used in the classroom.

INSERT ILLUSTRATION 7.1 ABOUT HERE

Copyright $($ Subversive Philosophy Memes, 2018

Although the idea to add customized memes to our class materials came directly from me (as coming up with philosophy-related memes is one of my secret geeky hobbies), something else was going on as well here. The following four memes, of which one is depicted above (Illustration 7.1), only came into being after thinking through the course materials with the students. When addressing Western idealist philosophies, for instance, the topic of Hegelian dialectics came up, which turned into a variety of Hegel memes that tackled not only the density but also the problematic difference-erasing qualities of Hegelian thought. The 
confrontation with Irigaray's obscure feminist psychoanalytical language in class engendered a meme with Irigaray's smiling face on it, and the text 'Irigaray: making her readers go bonkers since ' 74 '. One of the students was also convinced that Latour was 'one of those dead white male philosophers', and the meme with Latour's image and the imprint 'Latour is alive!' made us chuckle throughout our time together, while also helping us focus on why some of Latour's work could be regarded as problematic seen through several Indigenous perspectives. And last but not least, the meme illustrated above (Illustration 7.1) can be regarded as a somewhat cathartic expression of my own after having read Deleuze and Guattari while preparing to teach a session on pedagogies. Although I do not wish to overstate these memes' subversive power, they clearly came into being in response to several types of affect, such as confusion, joy and wonder, expressed by my undergraduates and myself when being confronted with several canonical and marginalized philosophical oeuvres. Bringing together different titbits of memories in unexpected new combinations and becoming some sort of cultural-pedagogical capital of their own after having been shared online, these memes possess diffractive pedagogic potential upon being re-used in the classroom. These memes not only relationally linked the students to innovative modes of digital image production and circulation, but they also clearly disrupted the image's representationalist function as such, while bringing all the co-learners in this course together via a shared humorous taunting and re-configurations of the Western philosophical canon. This affirmative yet critical engagement with the canon again underlined our dialogical and hierarchy-destabilizing encounters in the classroom.

These three diffraction examples demonstrate how theory and praxis may go hand in hand in feminist theory and philosophy, and how the presumed gaps between (feminist) new materialisms and the world may be blurred when these diffractive pedagogical strategies are 
engendered in - and bring new energy to - the classroom. Or as feminist new materialist pedagogues Anna Hickey-Moody and Tara Page have put it so nicely in Arts, Pedagogy, and Cultural Resistance: 'Practices, teaching and art production practices are modes of thought already in the act' (2016: 1). Matter has 'transformative capacities' (1), and '[n]ot only are we always with/in bodies, but we are always with matter' (4). Explicit feminist new materialist pedagogies, such as the aforementioned diffractive pedagogical strategies and principles, rise up from within the classroom, and materialize themselves in entanglement with the physicality of the classroom, the socio-cultural capital that is (re-)produced and/or disrupted, and the co-learners (students-and-teacher) participating in the course. The syllabus and midterm project are, in my view, particularly important diffractive pedagogical approaches. They both pull the teacher and students out of their self-reflexive minds and neoliberalpropelled hyper-individualized learning attitudes and, instead, accentuate the flows, passions, affects and intensities between them as co-learners. Furthermore, they express the new materialist idea that the teacher and the student, plus the teaching apparatuses and environment, are all interconnectedly involved (and transformed) when intra-actively collaborating with one another in the classroom.

\section{Afterthoughts. Diffraction 'versus' reflection?}

I end this chapter with some thoughts about diffraction and reflection and connect these to my earlier philosophical musings about the now-firmly established presence of neoliberal reason in higher education, and how feminist new materialist pedagogies have the power to subvert the latter. The potential complementarity of both diffractive and reflective pedagogical strategies has been touched upon before (see Bozalek and Zembylas, 2017) but it does not hurt to underline their co-existence again. Critical reflective methodologies can first of all not be that easily avoided, as we have all been disciplined by neoliberal reason that lauds the 
hyper-individualism and solipsism attached to reflection and (self-)reflexivity. Reflective pedagogical approaches and tools additionally still have their use in the classroom, because we, as co-learners, are operating within institutional frameworks and power relations that restrict us in our experiments with diffractive approaches. I am personally still a supporter of learning analysis assignments which, as self-reflexive pedagogical tools, ask the student to engage in an introspective moment, and are based upon a more representational, selfreferential learning model. And, interestingly enough, these moments of pure introspection, although self-reflexive, can oppose neoliberal reason, as they promote slow thinking. And, last but not least, it is not unimaginable that a reflection-based pedagogical tool ends up morphing into a diffractive one. To give an example: During my course, we all prepared for our classes by scribbling down notes and comments in the margins of assigned articles. These remarks and markings, often accompanied by colourful Post-its, were first introspective in nature but, when shared with one another in class by projecting them onto a screen, they became something more: They not only had the potential to become diffractive re-workings of the text in question - and the canonical knowledges that are represented by the textual - but also provided us with several moments of material encounters between a group of eventual co-learners. And this, to conclude, is exactly what diffraction does: It affectively provokes, makes us re-think what is traditional and canonical, and produces unexpected, creative outcomes.

\section{References}

Adorno, T. W. and Horkheimer, M. (1997/1944). Dialectic of Enlightenment, translated by John Cumming. London - New York: VERSO.

Alaimo, S. (2016). Exposed: Environmental Politics and Pleasures in Posthuman Times. Minneapolis: University of Minnesota Press. 
Aptheker, B. (1989). 'How to do Meaningful Work in Women's Studies', Women's Studies, $17(1-2), 5-16$.

Barad, K. (2000). 'Reconceiving Scientific Literacy as Agential Literacy’ in R. Reid and S. Traweek (Eds.) Doing Science + Culture. New York: Routledge.

Barad, K. (2001). 'Scientific Literacy ---> Agential Literacy = (Learning + Doing $)$ Science Responsibly’ in M. Mayberry, B. Subramaniam and L. H. Weasel (Eds.) Feminist Science Studies: A New Generation. New York, London: Routledge.

Barad, K. (2007). Meeting the Universe Halfway: Quantum Physics and the Entanglement of Matter and Meaning. Durham, London: Duke University Press.

Barad, K. (2010). 'Quantum entanglements and hauntological relations of inheritance: Dis/continuities, spacetime enfoldings, and justice-to-come', Derrida Today, 3(2), 240-268.

Bozalek, V. and Zembylas, M. (2017). 'Diffraction or reflection? Sketching the contours of two methodologies in educational research', International Journal of Qualitative Studies in Education, 30 (2), 111-127.

Braidotti, R. (2013). The Posthuman. Cambridge: Polity Press.

Braidotti, R. (2016). 'Don’t agonize, organize!', e-flux, https://conversations.eflux.com/t/rosi-braidotti-don-t-agonize-organize/5294, date accessed 10 March 2018.

Braidotti, R., Bozalek, V., Shefer, T. and Zembylas, M. (Eds.) (2018). Socially Just Pedagogies: Posthumanist, Feminist and Materialist Perspectives in Higher Education. London, New York: Bloomsbury Academic.

Brown, W. (2015). Undoing the Demos: Neoliberalism's Stealth Revolution. Brooklyn, NY: Zone Books. 
Choy, T. K., Faier, L., Hathaway, M. J., Inoue, M., Satsuka, S. and Tsing, A. (2009). 'A New Form of Collaboration in Cultural Anthropology: Matsutake Worlds', American Ethnologist, 36(2), 380-403.

Dardot, P. and Laval, C. (2013). The New Way of the World: On Neoliberal Society, translated by Gregory Elliott. London, New York: VERSO.

D. De Wachter (2012). Borderline Times: Het Einde van de Normaliteit. Leuven: LannooCampus.

Dolphijn, R. and van der Tuin, I. (2012). New Materialism: Interviews \& Cartographies. Ann Arbor: Open Humanities Press.

Foucault, M. (2008). The Birth of Biopolitics: Lectures at the Collège de France, 1978-79, edited by Michel Senellart and translated by Graham Burchell. New York: Picador.

Freire, P. (2001). Pedagogy of Freedom: Ethics, Democracy, and Civic Courage, translated by Patrick Clarke. Lanham, Boulder: Rowman \& Littlefield Publishers.

Freire, P. (2006). Pedagogy of the Oppressed, translated by Myra Bergman Ramos. New York, London: Continuum.

Geerts, E. and van der Tuin, I. (2016). 'Diffraction \& Reading Diffractively', New Materialism Almanac, http://newmaterialism.eu/almanac/d/diffraction, date accessed 10 March 2018.

Giroux, H. A. (1988). Teaching as Intellectuals: Toward a Critical Pedagogy of Learning. Westport, London: Bergin and Garvey.

Giroux, H. A. (2014). Neoliberalism's War on Higher Education. Chicago: Haymarket Books.

Groenke, S. L. and Amos Hatch, J. (Eds.) (2009). Critical Pedagogy and Teacher Education in the Neoliberal Era: Small Openings. Dordrecht: Springer. 
Haraway, D. J. (1988). 'Situated Knowledges: The Science Question in Feminism and the Privilege of Partial Perspective', Feminist Studies, 14(3): 575-599.

Haraway, D. J. (1997).Modest_Witness@Second_Millenium.

FemaleMan@_Meets_OncoMouseTM: Feminism and Technoscience. New York: Routledge.

Haraway, D. J. (2004). 'The Promises of Monsters: A Regenerative Politics for Inappropriate/d Others' in The Haraway Reader. New York and London: Routledge.

Haraway, D. J. (2016). Staying with the trouble: Making kin in the Chthulucene. Durham, London: Duke University Press.

Hickey-Moody, A. and Page, T. (Eds.) (2016). Arts, Pedagogy and Cultural Resistance: New Materialisms. London, New York: Rowman \& Littlefield.

hooks, b (1994). Teaching to Transgress: Education as the Practice of Freedom. New York, London: Routledge.

hooks, b. (2003). Teaching Community: A Pedagogy of Hope. New York, London: Routledge. Latour, B. (2005). 'From Realpolitik to Dingpolitik or How to Make Things Public' in Making Things Public. Atmospheres of Democracy, edited by Bruno Latour and Peter. Cambridge, MA: MIT Press.

Leatherby, L. (2016). 'US social mobility gap continues to widen', The Financial Times, https://www.ft.com/content/7de9165e-c3d2-11e6-9bca-2b93a6856354, date accessed 10 March 2018.

Nussbaum, M. C. (2010). Not for Profit: Why Democracy Needs the Humanities. Princeton and Oxford: Princeton University Press.

Peck, J. (2010). Constructions of Neoliberal Reason. Oxford, New York: Oxford University Press. 
Snaza, N., Sonu, D., Truman, S. E., and Zaliwska, Z. (Eds.) (2016). Pedagogical Matters: New Materialisms and Curriculum Studies. New York: Peter Lang.

Subversive Philosophy Memes (2018). https://estarthewicked.tumblr.com/, date accessed 1 March 2018.

UNdata (2018). 'Social Indicators', http://data.un.org/en/reg/g1.html, date accessed 3 March 2018.

UNESCO (2016). 'Education 2030. Incheon Declaration and Framework for Action for the implementation of Sustainable Development Goal 4', http://unesdoc.unesco.org/images/0024/002456/245656E.pdf, date accessed on March 52018.

UNESCO (2018). 'Education transforms lives', https://en.unesco.org/themes/education, date accessed 5 March 2018.

UNESCOstat (2017). 'Fact Sheet No. 45. September 2017. FS/2017/LIT/45 Literacy Rates Continue to Rise from One Generation to the Next' http://uis.unesco.org/sites/default/files/documents/fs45-literacy-rates-continue-risegeneration-to-next-en-2017_0.pdf, date accessed on March 52018.

van der Tuin, I. (2015). Generational Feminism: New Materialist Introduction to A Generative Approach. Lanham, Boulder: Lexington Books. 